\title{
Histological Effects of Calcium Chloride in Stored Apples
}

\author{
W. Robert Trentham \\ Department of Biology, Carson Newman College, Jefferson City, TN 37760 and Department of Plant \\ Sciences, The University of Tennessee, Knoxville, TN 37996 \\ Carl E. Sams ${ }^{1}$ \\ Department of Plant Sciences, The University of Tennessee, Knoxville, TN 37996 \\ William S. Conway \\ Produce Quality and Safety Laboratory, Henry A. Wallace Beltsville Agricultural Research Center, \\ Agricultural Research Service, U.S. Department of Agriculture, Beltsville, MD 20705
}

\begin{abstract}
AdDitional INDEX wORDs. Triple stain, periodic acid-Schiff's reagent, cuticle, epidermis, exocarp, Malus domestica
Abstract. Mature apples (Malus domestica Borkh. cv. Golden Delicious) were immersed for 2 min in 0, 0.14, 0.27, or $0.41 \mathrm{~mol} \cdot \mathrm{L}^{-1}\left(0,2 \%, 4 \%\right.$, or $6 \%$, respectively) aqueous solutions $(\mathrm{w} / \mathrm{v})$ of $\mathrm{CaCl}_{2}$ at 0 or $68.95 \mathrm{kPa}$, and were stored at $0{ }^{\circ} \mathrm{C}$. Histological samples of peel/cortex were taken at harvest and at four monthly intervals in storage. Paraffin sections were stained with an aqueous mixture of alcian blue 8GX, safaranin 0 and Bismark brown $Y$, or with the periodic acid-Schiff (PAS) reaction. No histological difference was observed in fruit treated with $2 \% \mathrm{CaCl}_{2} \mathbf{c o m p a r e d}$ with those pressure-infiltrated with greater amounts of Ca. Fruits pressure-infiltrated with $6 \% \mathrm{CaCl}_{2}$ exhibited the greatest amount of flattened epidermal cells and hypodermal cavities. Cuticles were also affected at the higher $\mathrm{CaCl}_{2}$ treatment levels (with regard to staining with Bismark brown), becoming more condensed and uniform. Cuticle and hypodermis were stained differentially with $\mathrm{PAS}$ in the $6 \% \mathrm{CaCl}_{2}$ treatment. All tissues, including the cuticle, were stained magenta red, indicating a possible chemical alteration of the cuticle and the underlying tissue by $\mathrm{Ca}$.
\end{abstract}

Many physiological and pathological disorders of apples are associated with the calcium content of the fruit tissues. It has been demonstrated that respiratory rate and ethylene production correlate negatively with $\mathrm{Ca}$ content in apples, both at harvest and in extended cold storage (Recasens et al., 2004). Increasing the $\mathrm{Ca}$ content of apples maintains fruit firmness, decreases the incidence of disorders such as water core, bitter pit, and internal breakdown (Bangerth et al., 1972; Dierend and Rieken, 2007; Faust and Shear, 1968; Marlow and Loescher, 1984; Raese and Drake, 2002; Reid and Padfield, 1975), and reduces decay caused by postharvest pathogens (Conway et al., 1991). Because the $\mathrm{Ca}$ concentration needed to control such maladies is usually higher than can be obtained with fertilization practices, the effects of the direct application of $\mathrm{CaCl}_{2}$ solutions to fruit and the resulting effects on storage quality have been investigated (Conway and Sams, 1983; Glenn and Poovaiah, 1985; Sams and Conway, 1984). It is generally accepted that Ca tissue concentrations should exceed $250 \mu \mathrm{g} \cdot \mathrm{g}^{-1}$ dry weight to control such physiological disorders as breakdown and bitter pit (Meheriuk and Moyls, 1989). To affect firmness or decay significantly, however, it is necessary to raise the tissue $\mathrm{Ca}$ level to 800 to $1000 \mu \mathrm{g} \cdot \mathrm{g}^{-1}$. Concentrations significantly higher than $1000 \mu \mathrm{g} \cdot \mathrm{g}^{-1}$ may cause surface injury to the fruit (Conway and Sams, 1985; Sams and Conway, 1984). Preharvest tree sprays have been used commercially to increase fruit $\mathrm{Ca}$ concentration. Research has shown preharvest treatments to improve fruit firmness, ratio of soluble solid concentration to titratable acidity (SSC:TA), and skin color (Kadir, 2005). However, even the recommended preharvest spray program adds only a

Received for publication 25 Mar. 2008. Accepted for publication 14 Apr. 2008. ${ }^{1}$ Corresponding author. E-mail: carlsams@utk.edu. small amount of $\mathrm{Ca}$ to the fruit, which is not enough to significantly reduce many postharvest physiological and pathological disorders (Yuen, 1994). The results are also extremely variable. In a study to determine tissue $\mathrm{Ca}$ increase in several apple cultivars through a seasonal spray program, even the desired concentration of $250 \mu \mathrm{g} \cdot \mathrm{g}^{-1}$ was not achieved (Conway et al., 1995). In a more recent preharvest spray investigation, the tissue Ca concentration of 'Golden Delicious' apple fruit was increased from 169 to $340 \mu \mathrm{g} \cdot \mathrm{g}^{-1}$ (Conway et al., 2002). This would be sufficient to alleviate some physiological maladies, but not nearly enough to significantly affect decay or firmness. Experimentally, pressure infiltration of apples with $\mathrm{CaCl}_{2}$ solutions increases the $\mathrm{Ca}$ concentration of apple fruit more effectively than spraying, dipping, or vacuum infiltration (Conway and Sams, 1983; Sams and Conway, 1984). In a pilot test using pressure infiltration of $\mathrm{CaCl}_{2}$ solutions at harvest, fruit tissue concentration was easily increased to at least the required amount of 800 to $1000 \mu \mathrm{g} \cdot \mathrm{g}^{-1}$ needed to beneficially affect decay and firmness in 'Golden Delicious' apples (Conway, et al., 1994). However, excessive infiltration of Ca solutions into the fruit can result in injury in the form of surface discoloration or lenticel pitting. The inability to predict potential injury to fruits is a major disadvantage of postharvest Ca treatment (Conway et al., 1994; Yuen, 1994). Injury could be a phytotoxic response to excess $\mathrm{Ca}$ in the fruit (Conway and Sams, 1985). Postharvest firmness retention is greater for calcium than for strontium or magnesium treatments, and injury is increased by magnesium relative to the other two elements (Conway and Sams, 1987). Ca-induced injury appears to be at least partly due to salt stress because injury severity increases with the concentration of $\mathrm{CaCl}_{2}$ in the solution with which the fruit is treated (Sharples and Johnson, 1976). It is 
possible that the pressure-infiltration procedure may also contribute to the injury symptoms that appear after treatment and storage. Therefore, the objective of this investigation was to histologically examine the effects of postharvest pressure infiltration of $\mathrm{CaCl}_{2}$ solutions into 'Golden Delicious' apples.

\section{Materials and Methods}

'Golden Delicious' apples were harvested in the preclimacteric stage from a commercial orchard in Pennsylvania and were randomized before treatment. Fruit were pressure infiltrated ( $3 \mathrm{~min}$ at $68.95 \mathrm{kPa}$ ) with distilled water or $0.14,0.27$, or $0.41 \mathrm{~mol} \cdot \mathrm{L}^{-1}(2 \%, 4 \%$, or $6 \%$, respectively) solutions of $\mathrm{CaCl}_{2} \cdot 2 \mathrm{H}_{2} \mathrm{O}$. After treatment, transverse sections through the peel and cortex were cut in triplicate from the "cheek" of the fruit and were immersed in $80 \%$ Histo Choice ${ }^{\circledR}$ (Amresco, Solon, $\mathrm{OH}$ ) and 20\% ETOH. Specimens in the fixative fluid were aspirated at $110 \mathrm{kPa}$ until they sank, which usually took about $1 \mathrm{~h}$. The aspirated fixative was replaced and fixation continued for $48 \mathrm{~h}$. The fixed specimens were dehydrated with an isopropanol series as follows: $30 \%$ and 50\%, $3 \mathrm{~h}$ each; $70 \%$ overnight; $90 \%$ and $95 \%, 2 \mathrm{~h}$ each; two changes of $100 \%, 1 \mathrm{~h}$ each, and a final change of $100 \%$. Isopropanol was evaporated and the specimens were infiltrated with paraffin (TissuePrep ${ }^{\circledR}$, MP 56 C; Thermo Fisher Scientific, Waltham, MA) for $24 \mathrm{~h}$ in a mechanical convection oven at $60{ }^{\circ} \mathrm{C}$. Specimen blocks were cast with stainless steel base molds and plastic block rings (Tissue-Tek ${ }^{\circledR}$; Electron Microscopy Sciences, Hatfield, PA).

Sections $10 \mu \mathrm{m}$ thick were cut with high-profile disposable blades on a rotary microtome. Ribbons of the sections were divided into segments, flattened on a water bath at $45^{\circ} \mathrm{C}$, and pulled off the water onto glass slides. Slides (Superfrost ${ }^{\circledR}$; Erie Scientific, Portsmouth, NH) were used directly from the package without washing and no adhesive was used to mount ribboned sections. Slide preparations were dried on a slide warmer overnight at $40^{\circ} \mathrm{C}$.

Several stains and staining techniques were tested to achieve optimal results. Included in the trials were alcian blue $8 \mathrm{GX}$, Bismarck brown $\mathrm{Y}$, azure $\mathrm{B}$, hematoxylin, toluidine blue $\mathrm{O}$, safranin $\mathrm{O}$, fast green FCF, and periodic acid-Schiff (PAS). The PAS reaction was used as reported for tomato (Solanum lycopersicum L.) exocarp (Graham, 1997). Ultimately, a novel mixture of three dyes [Bismarck brown Y (certified dye \#AcN9), alcian blue 8GX (certified dye \#ScAn-12), safranin $O$ (certified dye \#AcS-32)] was used (Graham and Trentham, 1998).

Slides with sections attached were immersed in the triple mixture and were stained through the paraffin medium. Staining was accomplished in Coplin jars warmed in a water bath at 50 ${ }^{\circ} \mathrm{C}$ for $1 \mathrm{~h}$ (Graham and Joshi, 1995, 1996). The stained slides were rinsed gently with tap water, blotted dry, and air dried overnight at $40^{\circ} \mathrm{C}$ on a slide warmer. Paraffin was extracted by moving the slides through four changes of MicroClear ${ }^{\circledR}$ solvent (Micron Environmental Industries, Fairfax, VA; $10 \mathrm{~min}$ in the first change, and $5 \mathrm{~min}$ in each of the remaining three changes) and through five changes of isopropanol $(5 \mathrm{~min}$ in the first rinse and $3 \mathrm{~min}$ in each of the remaining rinses) to remove the residual paraffin solvent. The alcohol-rinsed slides were air dried for $1 \mathrm{~h}$ and coverslips were affixed with Eukitt ${ }^{\circledR}$ resin (Electron Microscopy Sciences).

Results were recorded with a Nikon Optiphot microscope and UFX-II camera unit (Nikon, Melville, NY) on Kodak Ektachrome 64T transparency film (Eastman Kodak, Rochester,
NY) at $25 \times$. These images were copied onto $35-\mathrm{mm}$ Kodak Royal Gold 100 color print film using a Rokunar zoom slide duplicator (Aetna Optix, Island Park, NY) on a Canon EOS630 camera (Canon, Lake Success, NY) in bright sunlight. Printing and enlargement of the photomicrographs were done by a local commercial photography shop.

\section{Results}

Fruits that were pressure infiltrated with $6 \% \mathrm{CaCl}_{2}$ consistently showed more compressed hypodermal tissue than those infiltrated with $0 \% \mathrm{CaCl}_{2}$ (Fig. 1). This was evident in fruit before storage and as expected, appeared to become more pronounced as storage time increased to 3 and 4 months. Epidermal cells were also more flattened in the high Ca-treated fruit. Lenticels seemed to become more compressed and less accessible in the highest Ca-treated fruit (Fig. 2).

Cuticles appeared to be more compressed and uniform in the higher Ca-treated fruit, lacking the normal fractures and exposed cells characteristic of 'Golden Delicious' apple exocarp (Fig. 3). An unexpected result appeared in the process of PAS staining. This particular procedure was chosen because of its affinity for differentially staining the epidermis from all other tissue and substances present. PAS staining, including an aldehyde blockade control and cleansing properly with a freshly prepared $\mathrm{SO}_{2}$ rinse, produced an intense PAS staining in tomato fruit epidermis, whereas all other tissue and the cuticle remained unstained. It was hoped that the technique would work the same in apple exocarp. The outer wax layer, cuticle matrix, and the epidermis took on the dye in the fruit treated with $6 \% \mathrm{Ca}$, whereas samples exposed to lower or no $\mathrm{Ca}$ treatments displayed light staining in the epidermal/cuticle interface (Fig. 4).

\section{Discussion}

During postharvest infiltration of apples with $\mathrm{CaCl}_{2}$ solutions, $\mathrm{Ca}$ enters the fruit through lenticles (Betts and Bramlage, 1977; Harker and Ferguson, 1988) and through the calyx. However, cracks in the cuticle are also important pathways (Glenn and Poovaiah, 1985; Harker and Ferguson, 1988). The plant cuticle covers the fruit surface and serves as a protective barrier between the plant and its environment. The surface properties of fruit, particularly those of the cuticle, affect the absorption and distribution of applied chemicals such as $\mathrm{CaCl}_{2}$ solutions. Cracks in the outer cuticle are especially prevalent in 'Golden Delicious' apples early in the growing season. These cracks increase in width and number as the apple enlarges and matures (Meyer, 1944). By the end of the growing season, large cracks form an interconnected network on the surface of the apples (Faust and Shear, 1972). Lenticel permeability also increases during fruit development (Harker and Ferguson, 1988). Permeability to $\mathrm{CaCl}_{2}$ increases during apple development, as do the number of cracks in the outer wax layer (Glenn and Poovaiah, 1985). Cracks in the outer cuticle of apple fruit increases during the growing season, and the width and depth of the cracks continues to increase during cold storage. More $\mathrm{CaCl}_{2}$ solution enters apples pressure infiltrated after 6 months in storage than at harvest (Roy et al., 1999). Active infiltration, then, such as the use of pressure, is necessary to force the $\mathrm{CaCl}_{2}$ solution past the surface barriers into the fruit in adequate amounts to significantly affect the desired parameters. 

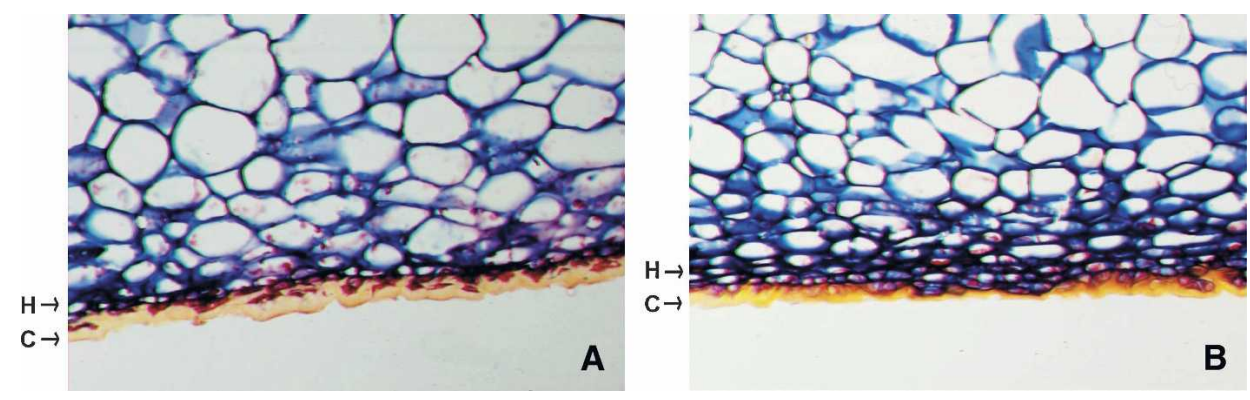

Fig. 1. (A) Apple peel of fruit pressure-infiltrated with $0 \% \mathrm{CaCl}_{2}$ showing a normal hypodermis and cuticle vs. (B) a fruit pressure-infiltrated with $6 \% \mathrm{CaCl}_{2}$ showing a compressed hypodermis and altered cuticle $(\times 50) . \mathrm{H}=$ hypodermis, $\mathrm{C}=$ cuticle.
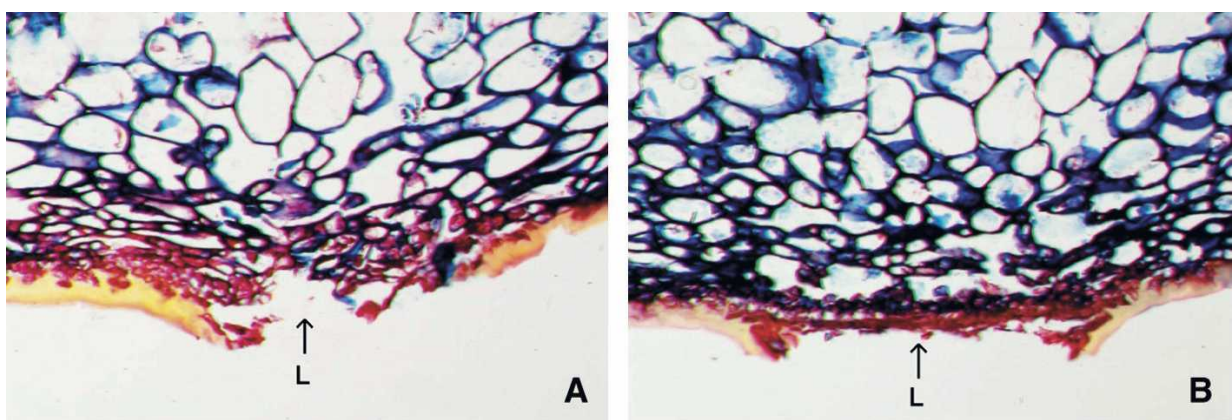

Fig. 2. (A) Apple peel perforated by a lenticle of fruit pressure-infiltrated with $0 \% \mathrm{CaCl}_{2}$ showing a normal passageway with hypodermal cavities for gas exchange vs. (B) a fruit pressure-infiltrated with $6 \% \mathrm{CaCl}_{2}$ showing a more compressed and inaccessible passageway $(\times 50) . \mathrm{L}=$ lenticle.

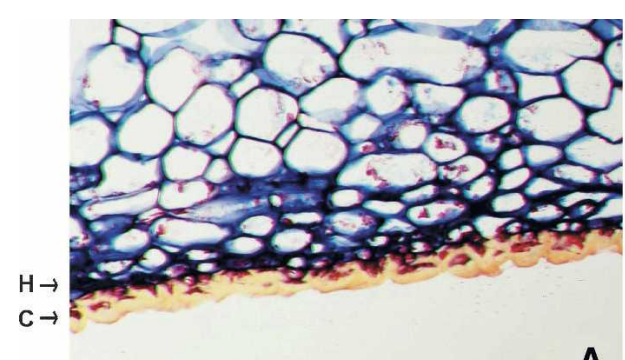

A

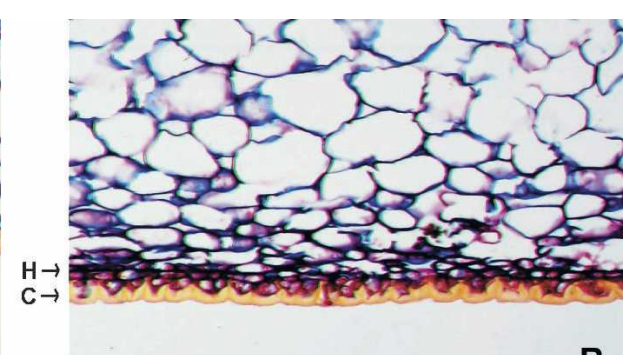

B
Fig. 3. (A) Apple peel of fruit pressure-infiltrated with $0 \% \mathrm{CaCl}_{2}$ showing a normal, robust cuticle with characteristic undulations vs. (B) a fruit pressure-infiltrated with $6 \% \mathrm{CaCl}_{2}$ showing a compressed, more uniform cuticle $(\times 50) . \mathrm{H}=$ hypodermis, $\mathrm{C}=$ cuticle.
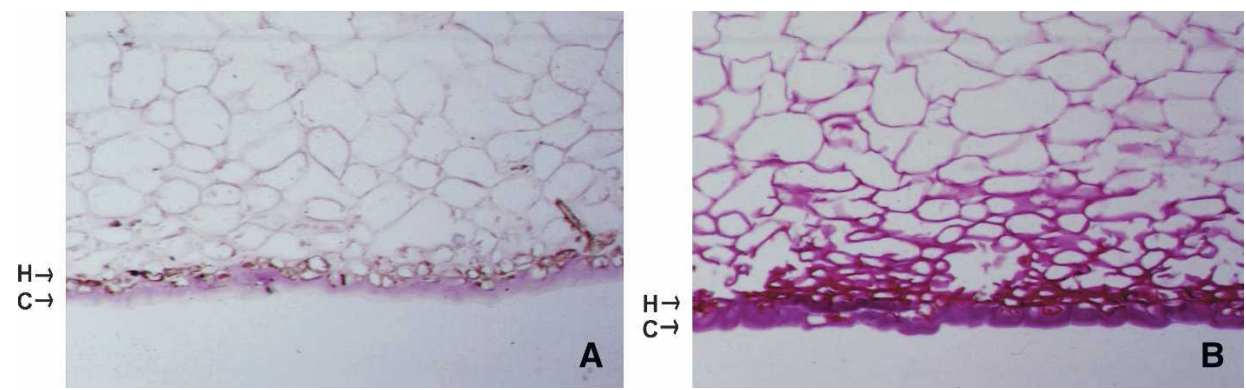

Fig. 4. (A) Apple peel of fruit pressure-infiltrated with $0 \% \mathrm{CaCl}_{2}$ showing differential periodic acid Schiff's staining (PAS) using an aldehyde blockade vs. (B) a fruit pressure-infiltrated with $6 \% \mathrm{CaCl}_{2}$ showing abnormal PAS stain retention by all tissue including cuticle $(\times 50) . \mathrm{H}=$ hypodermis, $\mathrm{C}=$ cuticle.
As indicated previously, infiltrating Ca solutions into apple fruit may also have deleterious effects on fruit physiology, which may lead to injury. Vacuum infiltration of $\mathrm{CaCl}_{2}$ solutions is effective in increasing the $\mathrm{Ca}$ tissue concentration in apple fruit, although not to the extent of that of pressure infiltration (Conway and Sams, 1983; Scott and Wills, 1979). Vacuum infiltration of apples with $\mathrm{Ca}$ solutions increased internal $\mathrm{CO}_{2}$ and decreased $\mathrm{O}_{2}$ levels in apple fruit (Hewett and Thompson, 1992). The Ca solution presumably floods intercellular spaces beneath lenticels, which normally provide a major diffusion route for gas movements into and out of fruit (Solomos, 1987). Although our results did not indicate a detrimental pressure influence, any treatment, such as vacuum infiltration, which potentially creates discontinuities in intercellular channels, is likely to impair movement of $\mathrm{O}_{2}$ within flesh tissues. The solution that enters the intercellular space in infiltration might block the air channels, thus reduce gas movement. Unfavorable $\mathrm{O}_{2}$ or $\mathrm{CO}_{2}$ levels generated in fruit internal atmospheres would lead to detrimental effects on internal produce quality, such as the development of physiological disorders (Rajapakse et al., 1992). Any physiological maladies caused by vacuum infiltration of $\mathrm{CaCl}_{2}$ solutions would presumably be exacerbated by pressure infiltration because significantly more solution is taken into the fruit by pressure infiltration (Conway and Sams, 1983).

In this study, fruit that is pressure infiltrated with $\mathrm{Ca}$ solutions exhibited more compressed hypodermal tissue and more flatten epidermal cells than those fruit pressure infiltrated with water. The cuticles were also more compressed and did not have the normal breaks, cracks, "tubes," and exposed cells normally exhibited by 'Golden Delicious' exocarp (Smock and Neubert, 1950). Although the epidermis of the mature apple fruit has been described as being composed of somewhat flattened or crushed cells (four cell layers thick) (Holloway, 1982), greater histological modification, such as that caused by calcium infiltration, could lead to 
detrimental physiological alterations. This is potentially more significant in 'Golden Delicious' apples due to their uneven cuticle and exposed cells in their exocarp. These abnormalities in the apple anatomy resulting from calcium infiltration could hinder gaseous exchange by flooding of the intercellular spaces with Ca solutions.

Our study did not indicate any observable change in the histological appearance of the tissues and cuticle of the apple exocarp due solely to the pressure-infiltration technique. There were also no marked differences observed between younger (at harvest) and older apples (at 4-month intervals) beyond what is normally anticipated in stored apples.

Although our observations are striking and there is little doubt that higher calcium concentration pressure infiltration is altering the histology and continuity in the apple exocarp, the precise cause is still unknown. Conway and Sams (1985) have alluded to a possible phytotoxic response to excess calcium; however, the literature has yet to widely support this assumption. Salt stress injury is better enunciated scientifically (Liu et al., 2006; Maiale et al., 2004; Sharples and Johnson, 1976), but the exact physical and chemical effects are still poorly understood. Further study could substantiate these variables.

The cuticle, secreted by and coating the epidermal tissue of higher plants, is a complex material consisting of two unique lipids, cutin and wax. A definable amount of the wax is embedded within the cutin (Holloway, 1982), as well as confined to a thin homogeneous film to the outside of the cutin matrix (Baker, 1982). Accordingly, these distinctive regions should technically be referred as to containing "intracuticular waxes" (Walton, 1990) and "epicuticular waxes" (Baker, 1982). Furthermore, there are unique chemical differences between intracuticular and epicuticular waxes, the composition of which fluctuates during development, occurring primarily in the epicuticular layer (Jetter and Schaffer, 2001). Aldehydes, the reactant in the PAS staining procedure, are a main constituent in the intracuticular matrix and epicuticular film. The PAS procedure we used employed an aldehyde blockade reagent: a saturated solution of 2,4 dinitrophenylhydrazine in $15 \%$ acetic acid (O'Brien and McCully, 1981). This measure should have prevented PAS positive staining in the tissue containing chemically complexed aldehydic components by preventing periodic acid oxidation. Apparently, mature 'Golden Delicious' apples naturally contain aldehydes in their intracuticular matrix layer that are somewhat impervious to this control measure. In addition, it appears that $\mathrm{Ca}$ infiltration treatments enhance periodic acid oxidation in all the tissues, including the intracuticular matrix and epicuticular film, affecting a positive PAS staining. Because the result is now known in only one apple cultivar at maturity, several obvious questions arise for further research in fruit physiology. If $\mathrm{Ca}$ is preventing the blockade from working, by what chemical means is it accomplished? Does the Ca by some mechanism enhance the effectiveness of the periodic acid in exposing the normally chemically complexed aldehyde groups so they can bind the stain? Any chemical alteration in the composition of the cuticle layer could further accelerate a decline in fruit quality. Additional research is needed to determine the exact physical and chemical cause of this effect.

The combination of a possible phytotoxic response to excess $\mathrm{Ca}$ in the fruit tissue and the potential chemical alteration of the cuticle layer, again intensified by increasing concentrations of the Ca solutions, add to the potential injury caused by pressure infiltration of $\mathrm{Ca}$ solutions into apple fruit. There is no doubt that increasing the $\mathrm{Ca}$ tissue concentration of apple fruit by postharvest treatment is quite beneficial in reducing physiological and pathological maladies in stored apple fruit. However, to avoid fruit injury, the development of a model system, which would predict the amount of Ca solution that would be taken into the fruit under a given pressure, is necessary if $\mathrm{Ca}$ infiltration is to ever be commercially adopted.

\section{Literature Cited}

Baker, E.A. 1982. Chemistry and morphology of plant epicuticular waxes, p. 139-165. In: D.F. Cutle, K.L. Alvin, C.E. Price (eds.). The plant cuticle. Academic Press, London.

Bangerth, F., D.R. Dilley, and D.H. Dewey. 1972. Effects of postharvest $\mathrm{Ca}$ treatment on internal breakdown and respiration of apple fruit. J. Amer. Soc. Hort. Sci. 97:679-682.

Betts, H.A. and W.J. Bramlage. 1977. Uptake of Ca by apples from postharvest dips in Ca chloride solutions. J. Amer. Soc. Hort. Sci. 102:785-788.

Conway, W.S. and C.E. Sams. 1983. Ca infiltration of 'Golden Delicious' apples and its effect on decay. Phytopathology 73: 1068-1071.

Conway, W.S. and C.E. Sams. 1985. Influence of fruit maturity on the effect of postharvest Ca treatment on decay of 'Golden Delicious' apples. Plant Dis. 69:42-44.

Conway, W.S. and C.E. Sams. 1987. The effects of postharvest infiltration of calcium, magnesium, or strontium on decay, firmness, respiration, and ethylene production in apples. J. Amer. Soc. Hort. Sci. 112:300-303.

Conway, W.S., C.E. Sams, J.A. Abbott, and B.D. Bruton. 1991. Postharvest $\mathrm{Ca}$ treatment of apple fruit to provide broadspectrum protection against postharvest pathogens. Plant Dis. 75:620-622.

Conway, W.S., C.E. Sams, G.A. Brown, W.B. Beavers, R.B. Tobias, and L.S. Kennedy. 1994. Pilot test for the commercial use of postharvest pressure infiltration of $\mathrm{Ca}$ into apples to maintain fruit quality in storage. HortTechnology 4:239-243.

Conway, W.S., C.E. Sams, and K.D. Hickey. 1995. Commercial potential for increasing apple tissue Ca sufficiently to maintain fruit quality in storage, p. 70-74. In: A. Ait-Oubahou and M. E.-Otmani (eds.). Postharvest physiology, pathology, and techniques for horticultural commodities. Institut Agronomique et Veterinaire Hassan II, Agadir, Morocco.

Conway, W.S., C.E. Sams, and K.D. Hickey. 2002. Pre- and postharvest $\mathrm{Ca}$ treatment of apple fruits and its effect on quality. Acta Hort. 594:413-419.

Dierend, W. and S. Rieken. 2007. Postharvest treatment of apples with Ca chloride. Erwerbs-Obstbau 49:51-56.

Faust, M. and C.B. Shear. 1968. Corking disorders of apples: A physiological and biochemical review. Bot. Rev. 34:441469.

Faust, M. and C.B. Shear. 1972. Fine structure of the fruit surface of three apple cultivars. J. Amer. Soc. Hort. Sci. 97:351-355.

Glenn, G.M. and B.W. Poovaiah. 1985. Cuticular permeability to Ca compounds in 'Golden Delicious' apples. J. Amer. Soc. Hort. Sci. 110:166-171.

Graham, E.T. 1997. Staining tomato fruit cuticle and exocarp tissues. Biotechnol. Histochem. 72:119-122.

Graham, E.T. and P.A. Joshi. 1995. Novel fixation of plant tissue, staining sections in the paraffin with alcian blue and hematoxylin, and improved slide preparation. Biotechnol. Histochem. 70:263266.

Graham, E.T. and P.A. Joshi. 1996. Plant cuticle staining with Bismarck brown $\mathrm{Y}$ and azure $\mathrm{B}$ or toluidine blue $\mathrm{O}$ before paraffin extraction. Biotechnol. Histochem. 71:92-95. 
Graham, E.T. and W.R. Trentham. 1998. Staining paraffin extracted, alcohol rinsed and air dried plant tissue with an agucous mixture of three dyes. Biotechnol. Histochem. 73:178-185.

Harker, F.R. and I.B. Ferguson. 1988. Transport of Ca across cuticles isolated from apple fruit. Scientia Hort. 36:205-217.

Hewett, E.W. and C.J. Thompson. 1992. Modification of internal carbon dioxide and oxygen levels in apple fruit by postharvest $\mathrm{Ca}$ application and modified atmospheres. Postharvest Biol. Technol. 1:213-219.

Holloway, P.J. 1982. Structure and histochemistry of plant cuticular membranes: An overview, p. 1-32. In: D.F. Cutler, K.L. Alvin, and C.E. Price (eds.). The plant cuticle. Academic Press, New York.

Jetter, R. and S. Schaffer. 2001. Chemical composition of the Prunus laurocerasus leaf surface. Dynamic changes of the epicuticular wax film during leaf development. Plant Physiol. 126:1725-1737.

Kadir, S.A. 2005. Influence of preharvest Ca application on storage quality of 'Jonathan' apples in Kansas. Trans. Acad. Sci. 108:129138.

Liu, J.H., K. Nada, C. Honda, H. Kitashiba, X.P. Wen, X.M. Pang, and T. Moriguchi. 2006. Polyamine biosynthesis of apple callus under salt stress: Importance of arginine decarboxylase pathway in stress response. J. Expt. Bot. 57:2589-2599.

Maiale, S., D.H. Sánchez, A. Guirda, A. Vidal, and O. Ruiz. 2004. Spermine accumulation under salt stress. J. Plant Physiol. 161:35-42.

Marlow, G.C. and W.H. Loescher. 1984. Watercore. Hort. Rev. (Amer. Soc. Hort. Sci.) 6:189-251.

Meheriuk, M. and L. Moyls. 1989. Augmentation of flesh Ca in apples by hydrostatic and pressure infiltration procedures. Can. J. Plant Sci. 69:565-568.

Meyer, A. 1944. A study of the skin structure of 'Golden Delicious' apples. Proc. Amer. Soc. Hort. Sci. 45:723-727.

O’Brien, T.P. and M.E. McCully. 1981. The study of plant structure. Termacarphi, Melbourne, Australia.
Raese, J.T. and S.R. Drake. 2002. Ca spray materials and fruit $\mathrm{Ca}$ concentrations influence apple quality. J. Amer. Pomol. Soc. 56:136143.

Rajapakse, N.C., E.W. Hewett, N. Banks, and D.J. Cleland. 1992. Vacuum infiltration with $\mathrm{Ca}$ chloride influences oxygen distribution in apple flesh. Postharvest Biol. Technol. 1:221-229.

Recasens, I., A. Benavids, J. Puy, and T. Casero. 2004. Preharvest Ca treatments in relation to the respiration rate and ethylene production of 'Golden Smoothee' apples. J. Sci. Food Agr. 84:765-771.

Reid, M.S. and C.A.S. Padfield. 1975. Control of bitter pit in apples with lecithin and Ca. N.Z. Expt. Agr. 7:379-381.

Roy, S., W.S. Conway, A.E. Watada, C.E. Sams, E.F. Erbe, and W.P. Wergin. 1999. Changes in the ultrastructure of the epicuticular wax and postharvest $\mathrm{Ca}$ uptake in apples. HortScience 34:121-124.

Sams, C.E. and W.S. Conway. 1984. Effect of Ca infiltration on ethylene production, respiration rate, soluble polyuronide content, and quality of 'Golden Delicious' apple fruit. J. Amer. Soc. Hort. Sci. 109:53-57.

Scott, K.J. and R.B.H. Wills. 1979. Effects of vacuum and pressure infiltration of $\mathrm{Ca}$ chloride and storage temperature on the incidence of bitter pit and low temperature breakdown of apples. Austral. J. Agr. Res. 30:917-928.

Sharples, R.O. and D.S. Johnson. 1976. Post-harvest chemical treatments for the control of storage disorders of apples. Ann. Appl. Biol. 83:157-167.

Smock, R.M. and A.M. Neubert. 1950. Apples and apple products. Interscience Publishers, New York.

Solomos, T. 1987. Principles of gas exchange in bulky plant tissues. HortScience 22:766-771.

Walton, T.J. 1990. Waxes, cutin and suberin, p. 106-158. In: J. Boyer (ed.). Methods in plant biochemistry. Academic Press, New York.

Yuen, C.M.C. 1994. Ca and fruit storage potential. Austral. Ctr. Intl. Agr. Res. 50:218-227. 